\title{
Down-regulation of beta catenin inhibits the growth of esophageal carcinoma cells
}

Nirmal K. Veeramachaneni, $\mathrm{MD}^{\mathrm{a}}$
Hirotoshi Kubokura, MD, $\mathrm{PhD}^{\mathrm{b}}$
Li Lin, MD
James A. Pippin, BA
G. Alexander Patterson, $\mathrm{MD}^{\mathrm{b}}$
Jeffrey A. Drebin, MD, PhD
Richard J. Battafarano, MD, PhD
From the Department of Surgery, ${ }^{a}$ Division of Cardiothoracic Surgery, ${ }^{b}$ and Hepatobiliary, Pancreatic and Gastrointestinal Surgery, ${ }^{c}$ Washington University School of Medicine, St Louis, Mo.

Read at the Eighty-third Annual Meeting of The American Association for Thoracic Surgery; Boston, Mass, May 4-7, 2003.

Supported by a research grant from the Thoracic Surgery Foundation for Research and Education.

Received for publication May 2, 2003; revisions requested May 2, 2003; revisions received June 18, 2003; accepted for publication June 25, 2003.

Address for reprints: Richard Battafarano, MD, PhD, Barnes Jewish Hospital, 1 Barnes Jewish Hospital Plaza, Queeny Tower Suite 3107, St Louis, MO 63110 (E-mail: BattafaranoR@msnotes.wustl.edu).

J Thorac Cardiovasc Surg 2004;127:92-8

0022-5223/\$30.00

Copyright (C) 2004 by The American Association for Thoracic Surgery

doi:10.1016/j.jtcvs.2003.06.008
Introduction: Esophageal cancer remains a highly lethal malignancy, with therapeutic options of limited efficacy in the majority of patients. Understanding the molecular events involved in the pathogenesis of esophageal cancer offers insight into potential targets for treatment. Beta catenin and Wnt signaling abnormalities are involved in the development of both adenocarcinoma and squamous carcinoma of the esophagus. We hypothesized that down-regulation of beta catenin would inhibit the growth of human esophageal cancer.

Methods: A human esophageal squamous cell carcinoma cell line (TE10) was treated with phosphorothioate antisense oligonucleotides to beta catenin. The cells were subsequently assayed for beta catenin mRNA and protein by real-time polymerase chain reaction and Western blot. Beta catenin transcriptional activity was determined by TOPFlash assay. Cell viability and growth was assessed by methylthiazol-diphenyl-tetrazolium assay and trypan blue exclusion. A colorimetric assay was employed to assess caspase 3 activity, and flow cytometry was done to determine percentage of cells in a given phase of the cell cycle.

Results: Following antisense treatment, beta catenin mRNA and protein concentration were decreased. There was corresponding decrease in beta catenin-transcription factor-dependent transcription. Treatment with beta catenin antisense resulted in significantly decreased cell viability and proliferation. The mechanism appears to be increased induction of apoptosis.

Conclusions: These data suggest a potential role for the targeting of beta catenin in the treatment of esophageal cancer.

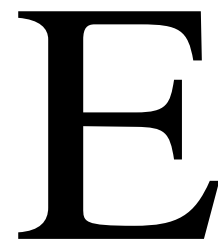

sophageal cancer ranks as the sixth most frequent cause of cancer death in the world and the seventh most common cause of cancer death in the United States. ${ }^{1}$ Despite significant advances in screening, surgical care, and chemoradiotherapy techniques, the overall 5-year survival for patients with esophageal cancer is $13 \% .^{2}$ Most of these treatment failures are due to metastatic disease resistant to systemic therapy. Although novel chemotherapeutic regimens are currently being developed, many patients are unable to tolerate the toxicities associated with these agents. Identification of the genetic defects responsible for the development of esophageal malignancies and the development of therapies that reverse these defects represent potentially useful adjuncts to the therapy of this lethal disease.

Beta catenin and other proteins in the Wnt signaling pathway play a role in the pathogenesis of many human cancers, including esophageal cancer. Beta catenin is involved in cell-cell adhesion by its interaction with the cytoskeleton and cadherin 
junctions. ${ }^{3}$ Beta catenin also serves as a transcription factor (TCF). ${ }^{4}$ Transcriptionally active beta catenin, derived from membrane bound beta catenin and a free cytoplasmic pool of beta catenin, ${ }^{5}$ is found in the nucleus and has been implicated in the transcription of oncogenes such as c-jun, ${ }^{6}$ c-myc, ${ }^{7}$ and cyclin D1. ${ }^{8}$ The adenomatous polyposis coli (APC) gene product forms a complex with other proteins, and targets beta catenin for degradation and prevents beta catenin-dependent transcription. ${ }^{9}$ Binding of the Wnt ligand to its transmembrane Frizzled $(\mathrm{Fz})$ receptors protects beta catenin from APC-mediated degradation and increases beta catenin-dependent transcription. ${ }^{10}$ Mutations in Wnt pathway elements have been described in both squamous cell carcinoma and adenocarcinoma of the esophagus. A number of histopathologic studies have shown abnormal localization of beta catenin in the nucleus in adenocarcinoma cells associated with Barrett's metaplasia. ${ }^{11}$ Mutations in beta catenin itself ${ }^{12,13}$ or in $\mathrm{APC}^{14}$ have been found infrequently in patients with esophageal adenocarcinoma. However, loss of heterozygosity in the APC gene was noted in $60 \%$ of adenocarcinoma arising from Barrett's metaplasia. ${ }^{15}$ In addition, there is an increased incidence of abnormal beta catenin expression in the sequence of low-grade dysplasia to adenocarcinoma of the esophagus. ${ }^{16}$ Gene profile experiments have demonstrated beta catenin to be one of very few genes to be differentially overexpressed in specimens of adenocarcinoma of the esophagus. ${ }^{17}$ Similarly, studies of squamous cell esophageal carcinomas have demonstrated increased cytoplasmic beta catenin, ${ }^{18}$ with no mutations in beta catenin itself. ${ }^{19}$ This increased cytoplasmic beta catenin may be due to the presence of a mutation in the Wnt receptor, the Fz gene product. In support of this hypothesis, Tanaka and colleagues ${ }^{20}$ have demonstrated an increased incidence (86\%) of activating mutations of the $\mathrm{Fz}$ gene product in the progression of well differentiated to poorly differentiated squamous cell carcinoma.

Targeted suppression of beta catenin using phosphorothioate antisense oligonucleotides has been demonstrated to inhibit the growth of colon cancer cells in vitro and in vivo by means of induction of apoptosis and cell cycle arrest (data submitted for publication). ${ }^{21}$ Because abnormal beta catenin expression is associated with neoplastic progression in esophageal cancer, we hypothesized that down-regulation of beta catenin would result in the inhibition of esophageal cancer cell growth. Using phosphorothioate antisense oligonucleotide directed against beta catenin mRNA, we have examined the role of beta catenin signaling in the neoplastic growth of esophageal cancer cells in vitro.

\section{Materials and Methods}

\section{Cell Lines}

Human esophageal cancer cell lines TE7, TE8, TE9, TE10, and TE11 were obtained from Dr Tetsuro Nishihira and Dr Toshio Kudo of Tohoku University, Sendai, Japan. These cell lines were cultured under usual conditions of $37^{\circ} \mathrm{C}$ under $5 \%$ carbon dioxide, in RPMI supplemented with $10 \%$ fetal bovine serum, 100 units $/ \mathrm{mL}$ penicillin, and $100 \mu \mathrm{g} / \mathrm{mL}$ streptomycin.

\section{Oligonucleotides and Cell Treatment Protocol}

Phosphorothioate oligonucleotides (ODN) directed against beta catenin were synthesized (Trilink Biotechnologies Inc, San Diego, Calif) as described previously. ${ }^{21}$ Beta catenin antisense sequence was 5'-TAAGAGCTTAACCACAACTG-3'. The scrambled control was 5'-CAGTAATCGAATAGCTACCA-3'. All experiments were done in triplicate, with both scrambled control and lipid carrier alone (Effectene; Qiagen, Valencia, Calif) treatment controls.

Antisense treatment was performed by plating $10^{6}$ cells into $100-\mathrm{mm}$ plates and allowing the cells to adhere overnight. Cells were washed in Optimem (Gibco, Grand Island, NY), and medium was replaced with one containing ODN for a 4-hour period. Transfection of ODN was mediated using the lipid carrier Effectene. On the basis of the manufacturer's recommendation, $15 \mu \mathrm{L}$ of Effectene was used to suspend $6 \mu \mathrm{g}$ of ODN, to a maximal concentration of $3.75 \mu \mathrm{L}$ Effectene/mL of RPMI medium. Cells were exposed to Effectene-ODN for 4 hours, then supplemented with fresh medium. This treatment was repeated 24 hours after initial treatment.

\section{Antibodies and Western Blots}

Total cellular protein extracts were obtained by lysis of tumor cells in lysis buffer $(50 \mathrm{mmol} / \mathrm{L}$ Tris- $\mathrm{HCl} \mathrm{pH} 7.4,5 \mathrm{mmol} / \mathrm{L}$ ethylene glycol tetraacetic acid (EGTA), 1\% Triton X-100, $150 \mathrm{mmol} / \mathrm{L}$ $\mathrm{NaCl}, 2 \mathrm{mmol} / \mathrm{L}$ phenylmethylsulfonyl fluoride, $1 \%$ aprotinin, and $5 \mu \mathrm{g} / \mathrm{mL}$ leupeptin) 48 hours after antisense treatment. Nuclearenriched cell extract was obtained by lysis of cells in low-salt buffer $(10 \mathrm{mmol} / \mathrm{L}$ HEPES, $10 \mathrm{mmol} / \mathrm{L} \mathrm{KCl}, 0.1 \mathrm{mmol} / \mathrm{L}$ ethylenediaminetetraacetic acid [EDTA], $0.1 \mathrm{mmol} / \mathrm{L}$ EGTA, 0.5 $\mathrm{mmol} / \mathrm{L}$ phenylmethylsulfonyl fluoride, $1 \%$ aprotinin, $5 \mu \mathrm{g} / \mathrm{mL}$ leupeptin, and $10 \% \mathrm{NP}-40 ; \mathrm{pH} 7.9)$, low speed $(0.4 g)$ centrifugation to pellet the nuclear fraction, and subsequent lysis in a high-salt buffer $(20 \mathrm{mmol} / \mathrm{L}$ HEPES, $0.4 \mathrm{~mol} / \mathrm{L} \mathrm{NaCl}, 1 \mathrm{mmol} / \mathrm{L}$ EDTA, $1 \mathrm{mmol} / \mathrm{L}$ EGTA, with $1 \%$ aprotinin and $5 \mu \mathrm{g} / \mathrm{mL}$ leupeptin). Protein concentration was obtained by Coomasie assay (Pierce; Rockford, Ill). Equal amounts of protein were subjected to sodium dodecyl-polyacrylamide gel electrophoresis and electrobotted onto PVDV membrane. Protein-specific antibodies directed against beta catenin, tubulin, and cyclin D1 were obtained from Santa Cruz Biotechnology (Santa Cruz, Calif) and Oncogene Research (Cambridge, Mass) and used according to manufacturer's recommendations. Alpha- and beta-tubulin-specific antibodies were used as control for equal protein loading. Appropriate secondary antibodies conjugated to horseradish peroxidase were used, and binding affinity assessed by electrochemoluminescence (Amersham Biosciences, Buckinghamshire, United Kingdom) exposure of radiographic film.

\section{Analyzing Beta Catenin mRNA Expression Using Real-Time Polymerase Chain Reaction Analysis}

Beta catenin mRNA levels were determined using a real-time polymerase chain reaction (RT-PCR) technique. In brief, total cellular RNA was extracted from TE10 cells with TRIzol reagent 
(Life Technologies, Carlsbad, Calif) 48 hours after treatment with antisense ODN directed against beta catenin. Using the Taqman assay system (Applied Biosystems, Foster City, Calif) cDNA was generated and subsequently amplified. Standardized primers specific for beta catenin and glyceraldehyde-3-phosphate dehydrogenase (Applied Biosystems) were used in this assay. To generate the standard curves, the crossing points of the standards were plotted against the logarithm of their concentrations (range $10^{10}$ to $10^{12}$ copies $/ \mathrm{mL}$ ). The thermal cycling conditions were an initial denaturation step at $95^{\circ} \mathrm{C}$ for 10 minutes, 40 cycles at $95^{\circ} \mathrm{C}$ for 15 seconds, and $60^{\circ} \mathrm{C}$ for 1 minute. An ABI Prism 5700 sequence detection system (Applied Biosystems) was used.

\section{Beta Catenin/TCF Reporter Assay}

Cells were treated with antisense in the described manner. Four hours after the second and final treatment, the culture medium was replaced and cells were transfected with TOPFlash (Upstate Biotechnology, Waltham, Mass) reporter vector. TOPFlash contains consensus sequence of Tcf/Lef enhancer, upstream of luciferase enzyme coding region. To serve as internal control for transfection, cells were cotransfected with a non-Tcf/Lef-dependent betagalactosidase coding vector. The ratio of TOPFlash to beta-galactosidase activity represented beta catenin/Tcf activity.

One million antisense-treated cells were cotransfected with 0.5 $\mu \mathrm{g}$ of TOPFlash vector and $2 \mu \mathrm{g}$ of beta galactosidase vector, using Effectene transfection reagent according to manufacturer's recommendations. Twenty-four hours after transfection, cells were lysed with cell culture lysis reagent (Promega; Madison, Wis), and beta galactosidase activity was measured with a beta galactosidase enzyme assay system (Promega). The same lysate was assayed for luciferase activity with a commercially available luciferase assay (Promega). Luciferase activity was normalized to beta galactosidase activity.

\section{FACScan/Cell Cycle Analysis}

Cells were detached from the plate with trypsin and fixed in cold $70 \%$ ethanol. Cells were then digested with solution containing RNAse A (100 units $/ \mathrm{mL}$, Roche) and stained with $50 \mu \mathrm{g} / \mathrm{mL}$ propidium iodide. DNA content was assessed with FACSscan flow cytometer, and analysis was done with FlowJo v 4.2 analysis software (Tree Star Inc, San Carlos, Calif).

\section{Cell Growth and Methyl-Thiazol-Diphenyl- \\ Tetrazolium Assay}

Viable cell number was determined counting trypan blue excluded cells. Methyl-thiazol-diphenyl-tetrazolium (MTT) assay was performed by plating antisense-treated cells into 96 well plates. MTT was added to each well for final concentration of $500 \mu \mathrm{g} / \mathrm{mL}$. After 4 hours of incubation at $37^{\circ} \mathrm{C}$, the fomazan product was solubilized in $10 \%$ sodium dodecyl/0.01N HCl. The absorbance of 595 $\mathrm{nm}$ was recorded, using 650-nm reference length (model 3550 Microplate Reader, Bio-Rad, Hercules, Calif). Results reported are the mean of 5 treatments.

\section{Apoptosis Determination}

Forty-eight hours after treatment, cells were detached from their plates with trypsin and washed in phosphate-buffered saline solution. Activation of caspase 3 was determined using ApoAlert
Caspase-3 Colorimetric Assay Kit (Clontech, Palo Alto, Calif), according to manufacturer's protocol. Annexin V staining was done using Annexin V-FITC Apoptosis Kit (BioSource International Inc, Camarillo, Calif), according to manufacturer's protocol.

\section{Statistical Analysis}

For Western blots, a representative blot from repeated experiments is shown. For other experiments, results represent the means of a minimum of triplicate samples and are presented as mean $\pm \mathrm{SE}$. Analysis of variance with Newman-Keuls multiple comparison test $(P<.05)$ defined significance.

\section{Results}

Esophageal Cancer Cell Lines Contain Beta Catenin Multiple esophageal cancer cell lines were examined for beta catenin protein expression. Although Western blotting revealed beta catenin in all esophageal cancer cell lines, the greatest expression was noted in the highly differentiated squamous cell carcinoma cell lines TE10 and TE11 cells lines (Figure 1, A). We chose to use the TE10 cell line in subsequent experiments.

\section{Antisense Treatment Decreases Beta Catenin mRNA and Protein Expression}

Treatment of esophageal cancer cells with antisense ODN directed against beta catenin resulted in decreased levels of beta catenin mRNA, relative to scramble treatment $(51 \%$ reduction; $P<.01$; Figure $1, B)$, and decreased nuclear beta catenin protein levels 48 hours after initial treatment (Figure $1, C)$. Although beta catenin protein levels in the total cell lysate was minimally decreased at this 48 hour time point (data not shown), there was a marked reduction in beta catenin protein in the nuclear fraction. This difference likely reflects the slow turnover of membrane-bound beta catenin.

\section{Antisense Treatment Decreases Beta Catenin-Dependent Transcription}

Because total cellular lysates contain beta catenin bound to the cell membrane and the nuclear contents containing transcriptionally active beta catenin, evaluation of the nuclear fraction alone is a better indication of changes in transcriptionally active beta catenin. In an effort to determine whether the decreased nuclear beta catenin resulted in decreased beta catenin transcriptional function, we performed a beta catenin/Tcf-sensitive reporter assay.

Following ODN treatment, a luciferase reporter gene under the control of a beta catenin/Tcf-sensitive element was transfected into TE10 cells. We noted a 36\% decrease in luciferase reporter activity in cells treated with beta catenin ODN relative to scrambled control (Figure 1, D). Esophageal cancer cell viability and growth is inhibited by beta catenin antisense treatment. In a representative experiment, treatment with phosphorothioate antisense oligonucleotide resulted in significant inhibition of cell growth by 
A.

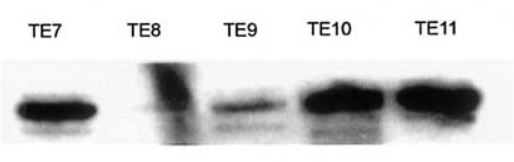

B.

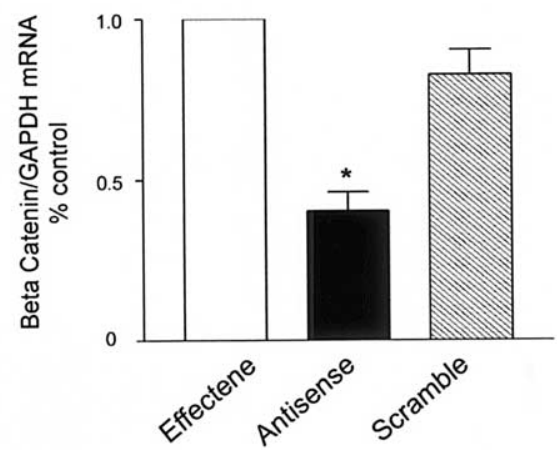

C.

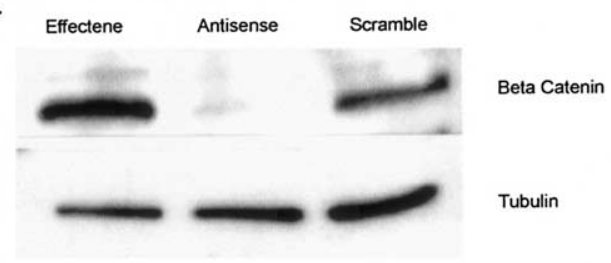

D.

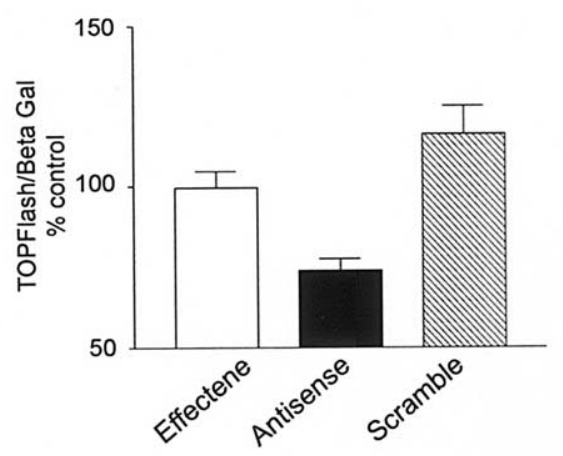

Figure 1. A, Western blot revealed variable beta catenin protein expression in TE cell lines assayed. The greatest concentration was noted in TE10 and TE11 cell lines. Protein was loaded (10 $\mu \mathrm{g}$ per lane). Equal concentration of tubulin was present. B, RT-PCR showed decrease in beta catenin mRNA copy number relative to controls $(P<.01)$. C, Western blot of nuclear lysate derived from antisense treated cells was devoid of beta catenin. D, TOPFlash, a beta catenin-depended luciferase assay, demonstrated decreased luciferase activity, with beta catenin antisense treatment.

MTT assay 3 days after single treatment, compared with scrambled control (59\% reduction, $P<.01$; Figure $2, A$ ). Treatment of cells with oligonucleotide on consecutive days had similar effect on directly measured cell growth. There was an $80 \%$ decrease in cell number, with beta catenin antisense treatment relative to scrambled control $(P<.01$; Figure 2, $B$ ).

\section{Caspase 3 Activity Is Increased by Beta Catenin Antisense Treatment}

We sought to determine the mechanism responsible for the beta catenin antisense-mediated inhibition of TE10 cell growth. A decrease in the number of viable cells may be due to induction of apoptosis. Caspase 3, a protease, is the terminal effector of the apoptotic pathway. Direct colorimetric assay of caspase 3 activity showed increased activity with antisense treatment relative to scrambled control (59\%; $P<.01$; Figure 3, A). This increase in directly measured caspase activity was corroborated with annexin staining for apoptotic cells (data not shown).

Inhibition of TE10 Cell Growth Is Not Associated with Cell Cycle Arrest

Cell cycle arrest may also contribute to growth inhibition. Cyclin D1 expression is necessary for the progression of the cell through the G0/G1 phase of the cell cycle, and its expression is transcriptionally regulated by beta catenin/Tcf in some cells. We hypothesized that down-regulation by beta catenin would be associated with a decrease in cyclin D1 and increase in the number of cells in the G0/G1 phase of the cell cycle. However, in TE10 cells, down-regulation of beta catenin was not associated with a decrease in cyclin D1 expression, and cell cycle analysis revealed no change in the fraction of esophageal tumor cells in the G0/G1 phase of the cell cycle (Figure 3, $B$ and $C$ ).

\section{Discussion}

Beta catenin and elements of the Wnt signaling elements have been found to play an important role in the pathogenesis of human cancer. Phosphorothioate antisense oligonucleotides provide a potent technology to specifically inhibit a given mRNA target. We have previously demonstrated antisense-mediated down-regulation of beta catenin expression in multiple human colon cancer cell lines containing increased beta catenin activity, with resulting inhibition of cell growth in vitro and in vivo. ${ }^{22}$ Beta catenin mRNA and protein levels in the colon cancer xenografts were significantly depressed after ODN treatment. In this colon cancer model, inhibition of cell growth was mediated both by cell 


\section{A. MTT Assay}

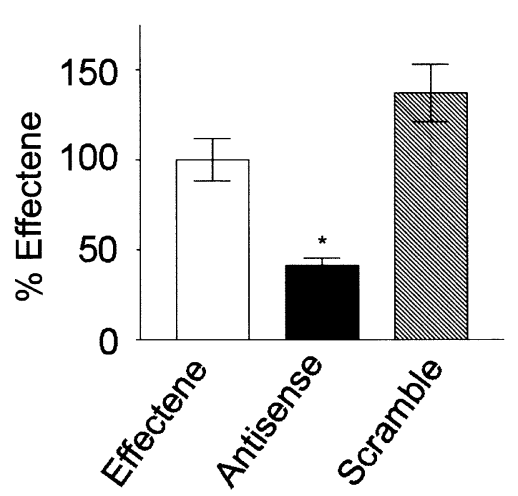

B. Cell Count

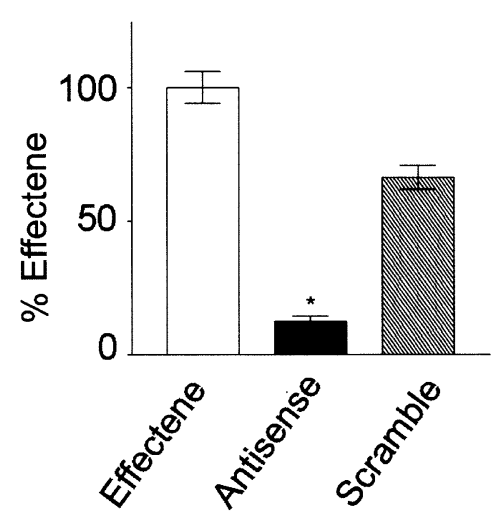

Figure 2. MTT assay performed 3 days after treatment demonstrated significant decrease in cell viability in those cells treated with beta catenin phosphorothioate antisense oligonucleotide $(P<.01)$.

A.

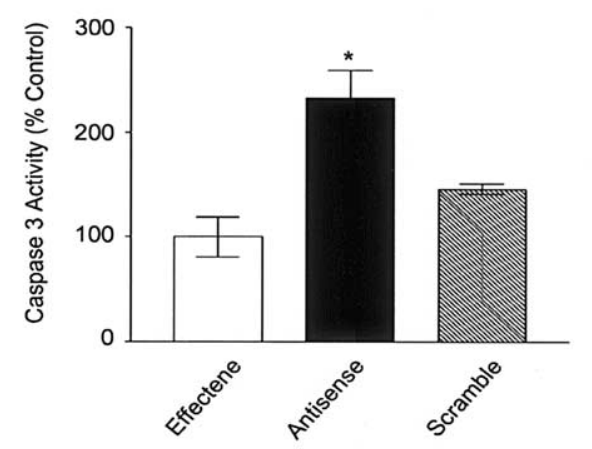

C.

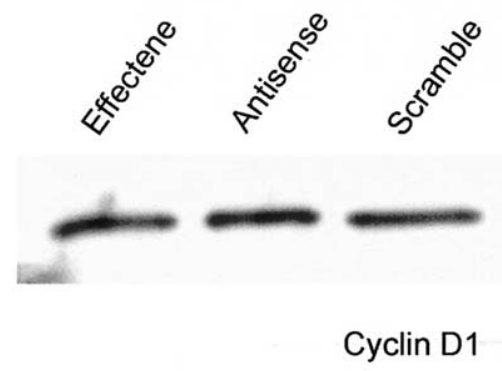

B.

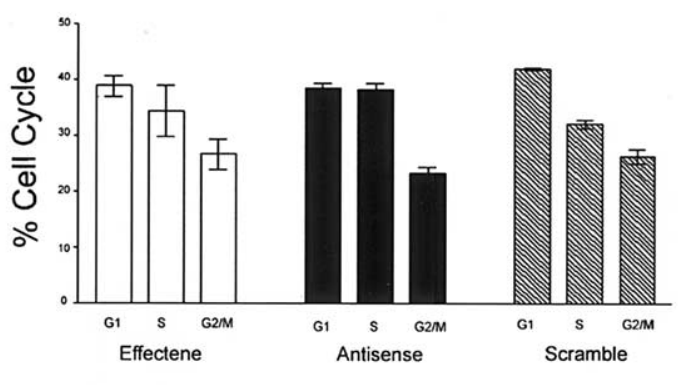

Figure 3. Direct assay of cell viability by trypan blue staining similarly demonstrated significant decrease in cell growth in those cells treated with beta catenin phosphorothioate antisense oligonucleotide $(P<.01)$.

cycle arrest and induction of apoptosis (data submitted for publication).

In the current study, inhibition of beta catenin by specific phosphorothioate antisense oligonucleotides resulted in a significant decrease in esophageal cancer cell growth. This inhibition was characterized by induction of apoptosis but not cell cycle arrest. In contrast to beta catenin signaling in colon cancer cells, down-regulation of beta catenin in esophageal cancer cells did not result in a decrease in cyclin D1 expression. Collectively these findings suggest that regulation of cyclin D1-mediated cell cycle progression in TE10 cells occurs independently of beta catenin/Tcf-mediated transcription. This finding may be clinically significant because increased cyclin D1 expression has been demonstrated to be a poor prognostic sign in patients with esophageal cancer. ${ }^{23}$ As an alternative, the EGFR pathway has 
been demonstrated to be activated in esophageal malignancies, as well as our esophageal cancer model, and is known to regulate cyclin D1 expression. ${ }^{24}$

Despite this apparent lack of inhibition of cell cycle progression, we did document decreased cancer cell growth, possibly by means of apoptotic induction. The specific mechanism of induction of apoptosis remains to be elucidated. Apoptotic signaling pathways arising from the mitochondria as well as receptors, and structural components of the cell membrane have been identified. ${ }^{25}$ Activation of Wnt signaling has been shown to inhibit induction of apoptosis. ${ }^{26}$ Because many chemotherapeutic agents function by inducing apoptosis, activation of the Wnt signaling pathway through beta catenin may lead to chemotherapeutic resistance. ${ }^{26}$

The use of oligonucleotides to inhibit a specific protein's expression and cause a desired inhibition of growth has been demonstrated in a number of tumor models. When appropriately designed, phosphorothioate oligonucleotides have high degree of specificity to their target and have minimal nonspecific effects, such as activation of inflammatory response in vivo. ${ }^{27}$ In preliminary work, we have demonstrated inhibition of polyp formation in the intestines of APC mutant mice, using long-term antisense treatment targeting murine beta catenin. ${ }^{28}$ The mice appeared to tolerate systemic down-regulation of beta catenin, perhaps because of biological redundancy, and the ability of other proteins to substitute for the functions of beta catenin. ${ }^{29}$ Antisense compounds have also been shown to potentiate the effects of chemotherapeutic agents.

This initial study has demonstrated the inhibition of the growth of squamous cell carcinoma of the esophagus by down-regulation of beta catenin. There exists a potential benefit for combining beta catenin antisense treatment with traditional chemotherapeutic agents. Preliminary work in a colon cancer xenograft model using this same antisense ODN has shown significant inhibition of tumor cell growth with the combination of beta catenin antisense oligonucleotides and conventional chemotherapeutic agents. ${ }^{30}$ Antisense targeting of beta catenin may have a role in the development of potent treatments for cancer of the esophagus.

\section{References}

1. Pisani P, Parkin DM, Ferlay J. Estimates of the worldwide mortality from eighteen major cancers in 1985. Implications for prevention and projections of future burden. Int J Cancer. 1993;55:891-903.

2. Greenlee RT, Hill-Harmon M, Murray T, Thun M. Cancer statistics, 2001. CA Cancer J Clin. 2001;51:15-36.

3. Orsulic S, Huber O, Aberle H, Arnold S, Kemler R. E-cadherin binding prevents beta-catenin nuclear localization and beta-cateninLEF-1-mediated transactivation. J Cell Sci. 1999;112:1237-45.

4. Morin PJ, Sparks AB, Korinek V, et al. Activation of beta-catenin-Tcf signaling in colon cancer by mutations in beta-catenin or APC. Science. 1997;275:1787-90.
5. Klingelhofer J, Troyanovsky RB, Laur OY, Troyanovsky S. Exchange of catenins in cadherin-catenin complex. Oncogene. 2003;22:1181-8.

6. Mann B, Gelos M, Siedow A, et al. Target genes of beta-catenin-T cell-factor/lymphoid-enhancer-factor signaling in human colorectal carcinomas. Proc Natl Acad Sci U S A. 1999;96:1603-8.

7. He TC, Sparks AB, Rago C, et al. Identification of c-MYC as a target of the APC Pathway. Science. 1998;281:1509-12.

8. Tetsu O, McCormick F. Beta-catenin regulates expression of cyclin D1 in colon carcinoma cells. Nature. 1999;398:422-6.

9. Aberle H, Bauer A, Stappert J, Kispert A, Kemler R. Beta-catenin is a target for the ubiquitin-proteasome pathway. EMBO J. 1997;16:3797804.

10. Cadigan KM, Nusse R. Wnt signaling: a common theme in animal development. Genes Dev. 1997;11:3286-305.

11. Osterheld MC, Bian YS, Bosman FT, Benhattar J, Fontolliet C. Betacatenin expression and its association with prognostic factors in adenocarcinoma developed in Barrett esophagus. Am J Clin Pathol. 2002; 117:451-6

12. Choi YW, Heath EI, Heitmiller R, Forastiere AA, Wu TT. Mutations in beta-catenin and APC genes are uncommon in esophageal and esophagogastric junction adenocarcinomas. Mod Pathol. 2000;13:1055-9.

13. Bian YS, Osterheld MC, Bosman FT, Fontolliet C, Benhattar J. Nuclear accumulation of beta-catenin is a common and early event during neoplastic progression of Barrett esophagus. Am J Clin Pathol. 2000; 114:583-90.

14. Wijnhoven BP, Nollet F, De Both NJ, Tilanus HW, Dinjens WN. Genetic alterations involving exon 3 of the beta-catenin gene do not play a role in adenocarcinomas of the esophagus. Int $J$ Cancer. 2000;86:533-7.

15. Gonzalez MV, Artimez ML, Rodrigo L, et al. Mutation analysis of the p53, APC, and p16 genes in the Barrett's oesophagus, dysplasia, and adenocarcinoma. J Clin Pathol. 1997;50:212-7.

16. Sheng H, Shao J, Williams CS, et al. Nuclear translocation of betacatenin in hereditary and carcinogen-induced intestinal adenomas. Carcinogenesis. 1998;19:543-9.

17. Hourihan RN, O'Sullivan GC, Morgan JG. Transcriptional gene expression profiles of oesophageal adenocarcinoma and normal oesophageal tissues. Anticancer Res. 2003;23:161-5.

18. Kimura Y, Shiozaki H, Doki Y, et al. Cytoplasmic beta-catenin in esophageal cancers. Int J Cancer. 1999;84:174-8.

19. Sanders DS, Bruton R, Darnton SJ, et al. Sequential changes in cadherin-catenin expression associated with the progression and heterogeneity of primary oesophageal squamous carcinoma. Int J Cancer. 1998;79:573-9.

20. Tanaka S, Akiyoshi T, Mori M, Wands JR, Sugimachi K. A novel frizzled gene identified in human esophageal carcinoma mediates APC/beta-catenin signals. Proc Natl Acad Sci $U$ S A. 1998;95:10164-9.

21. Roh H, Green DW, Boswell CB, Pippin JA, Drebin JA. Suppression of beta-catenin inhibits the neoplastic growth of APC-mutant colon cancer cells. Cancer Res. 2001;61:6563-8.

22. Green DW, Roh H, Pippin JA, Drebin JA. Beta-catenin antisense treatment decreases beta-catenin expression and tumor growth rate in colon carcinoma xenografts. J Surg Res. 2001;101:16-20.

23. Imamura M, Research Committee on Malignancy of Esophageal Cancer, Japanese Society for Esophageal Diseases. Prognostic significance of cyclinD1 and E-cadherin in patients with esophageal squamous cell carcinoma: multiinstitutional retrospective analysis. J Am Coll Surg. 2001;192:708-18.

24. Yan YX, Nakagawa H, Lee MH, Rustgi AK. Transforming growth factor-alpha enhances cyclin D1 transcription through the binding of early growth response protein to a cis-regulatory element in the cyclin D1 promoter. J Biol Chem. 1997;272:33181-90.

25. Jaattela M. Programmed cell death: many ways for cells to die decently. Ann Med. 2002;34:480-8.

26. Chen S, Guttridge DC, You Z, et al. Wnt-1 signaling inhibits apoptosis by activating b-catenin/T cell factor-mediated transcription. $J$ Cell Biol. 2001;152:87-96.

27. Green DW, Roh H, Pippin J, Drebin JA. Antisense oligonucleotides: 
an evolving technology for the modulation of gene expression in human disease. J Am Coll Surg. 2000;191:93-105.

28. Green DW, Roh H, Pippin JA, Mokadam NA, Drebin JA. Suppression of b-catenin blocks proliferation in spontaneous intestinal adenomas of APC-mutant (min) mice. Surg Forum. 2001;52:223-5.

29. Kolligs FT, Kolligs B, Hajra KM, et al. Gamma-catenin is regulated by the APC tumor suppressor and its oncogenic activity is distinct from that of beta-catenin. Genes Dev. 2000;14:1319-31.

30. Mokadam NA, Roh H, Pippin JA, Drebin JA. Antisense suppression of b-catenin enhances the chemosensitivity of colon carcinoma cells. Ann Surg Oncol. 2002;9:S35.

\section{Discussion}

Dr W. Roy Smythe (Houston, Tex). I have 2 questions about your assays that you did after your antisense treatment. First, did you look at the other catenins for the cadherins to make sure that with your antisense you weren't actually down-regulating multiple components of that pathway by Western blot or other means?

And second, do you have an idea of sort of the overall amount of apoptosis as measured by either subG1 FACS or annexin V or something like that? I don't really have a good idea about just how much apoptosis you're seeing with an increase in caspase 3 activity.

Dr Veeramachaneni (St Louis, Mo). In answer to your first question, we did not specifically look at cadherins in this population of cells.

As for means of apoptosis, you're absolutely right. One measure of apoptosis, such as caspase 3, is not enough to prove our point. We corroborated our caspase 3 assay using annexin V staining and we were able to show an increase in apoptotic cells.

Dr Smythe. What would you say the total percentage of apoptosis is by annexin V?

Dr Veeramachaneni. About 10\% after a single treatment at 24 hours after treatment.

Dr Smythe. So an elevation that's still a pretty low amount?

Dr Veeramachaneni. Correct.

Dr David A. Jones (Charlottesville, $\mathrm{Va}$ ). What was your timeline for apoptosis with your antisense treatment? How long did it last? How long did it take before you saw some apoptosis?

And also, did you do any studies kind of looking at the end gene products of the beta catenin signaling pathway such as cyclin D1 or some of your metalloproteinases by either at a protein or an mRNA level once you treated with the antisense?

Dr Veeramachaneni. Looking at other downstream targets of the Wnt signaling pathway was rather interesting in these cells. Most of our laboratory's experience is in the colon cancer cell line. In the colon cancer cell lines, we note not only an induction of apoptosis but also cell cycle arrest with targeting of beta catenin. In those cell lines we were able to show a decrease in cyclin D1 and associated FACS analysis increase in G1 fraction.

These (TE10) cell lines, however, don't behave that way. When we specifically looked at cell cycle inhibition as a potential role in how beta catenin antisense is working, we were not able to demonstrate that mechanism. We saw no change in cyclin D1 expression both by RT-PCR as well as protein expression.

We also looked at a number of other targets of the beta catenin signaling pathway we were able to demonstrate MDR inhibition. MDR is another name for P-glycoprotein and has been implicated in chemoresistance.

As far as the first part of your question, looking at the maximal time for apoptosis, we translated what we knew from our colon cancer cell model to this cell model. In the colon cancer cell model, we see a decrease in beta catenin as early as 30 minutes after antisense treatment, the effect lasts for about 3 days, and maximal apoptotic activity is seen at about 48 to 72 hours. And we chose the same time points in this study.

Dr Raphael Bueno (Boston, Mass). Do you know what happens when you put beta catenin into normal cells? I mean, do all cells get apoptotic and die, or do specific cancer cells only get apoptotic and die?

Dr Veeramachaneni. I'm sorry, did you ask if by inhibiting beta catenin whether all cells die?

Dr Bueno. I mean, did you just do the experiments in colon cancer and then in esophageal cancer cell lines, or did you do it in some cell lines that do not die? I'm just trying to figure out if this is a general necessary gene that if you inhibit it anything dies, or is it a specific mechanism of esophageal cancer and if you inhibit it, the cancer cells die?

Dr Veeramachaneni. We looked at a number of colon cancer cell lines, some of which have high levels of beta catenin expression as well as function. In those cell lines that do not have an avid Wnt signaling cascade, beta catenin antisense has no effect.

So the short answer to your question is, this is a specific process. In our experience, if the cell line does not have an active Wnt signaling pathway driving the carcinogenic pathway, this probably has no effect.

Dr Dao M. Nguyen (Bethesda, Md). Have you done any immunostaining to find out the cell localizations of beta catenin, which is very highly expressed in this cell line?

Dr Veeramachaneni. In these cell lines we have not done those studies. 